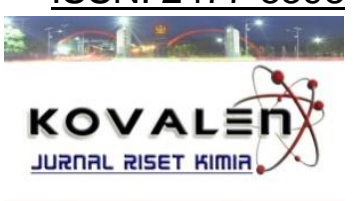

\title{
PRODUKSI DAN UJI AKTIVITAS ENZIM KITINASE DARI ISOLAT BAKTERI TERMOFILIK B1211 ASAL AIR PANAS BORA
}

\section{[Production and Activity Assay of Chitinase Enzyme from B1211 Thermophyl Bacteria Isolates in Bora Hot Springs]}

\author{
Jaya Hardi ${ }^{{ }^{*}}$, Jusman ${ }^{1}$, Abd. Rahman Razak ${ }^{1}$, Silva $^{1}$ \\ 1 Jurusan Kimia Fakultas MIPA, Universitas Tadulako \\ Jl. Soekarno Hatta Km.9, Kampus Bumi Tadulako Tondo Palu, Telp. 0451- 422611
}

Diterima 23 Agustus 2016, Disetujui 23 Oktober 2016

\begin{abstract}
This research aims to production of chitinase from thermophylic bacteria that living in Bora hot spring and to determine of chitinase extracts activity. The research was began with rejuvenated of B1211 bacteria isolates on MSM agar media. The B1211 isolates was used to production of chitinase extracts on MSM broth media with chitin colloidal concentration of $0.25 \%, 0.5 \%, 1 \%, 2 \%, 4 \%$ and incubation temperature of $30^{\circ} \mathrm{C}(\mathrm{rt}), 37^{\circ} \mathrm{C}, 50^{\circ} \mathrm{C}$, and $60^{\circ} \mathrm{C}$ for 3 days. The chitinase activity were analyzed based on $\mathrm{N}$-acetyl-D-glucosamine standard. The results was showed that B1211 bacteria isolates is potential isolate for production chitinase. The highest activity of chitinase from B1211 bacteria isolates of $0.75 \mathrm{U} / \mathrm{mL}$ for chitin colloidals concentration of $1 \%$ and temperature of $60^{\circ} \mathrm{C}$.
\end{abstract}

Keywords : Bora, hot spring, bacteria, thermophylic, B1211 isolates, chitinase.

\begin{abstract}
ABSTRAK
Penelitian ini bertujuan untuk memproduksi enzim kitinase dari bakteri termofilik asal sumber air panas Bora dan untuk menentukan aktivitas enzim kitinase yang diperoleh. Penelitian diawali dengan peremajaan isolat bakteri B1211 pada media MSM agar. Isolat bakteri B1211 digunakan untuk produksi enzim kitinase pada media MSM cair yang diperkaya dengan konsentrasi koloidal kitin $0,25 \%, 0,5 \%, 1 \%$, dan $4 \%$ pada suhu inkubasi $30^{\circ} \mathrm{C}(r t), 37^{\circ} \mathrm{C}, 50^{\circ} \mathrm{C}$, dan $60^{\circ} \mathrm{C}$ selama 3 hari. Aktivitas enzim kitinase dianalisis berdasarkan standar $\mathrm{N}$-asetil-D-glukosamin. Hasil penelitian menunjukkan bahwa isolat bakteri B1211 adalah isolat yang sangat potensial digunakan untuk produksi kitinase. Aktivitas enzim kitinase tertinggi dari isolat bakteri B1211, yaitu $0,75 \mathrm{U} / \mathrm{mL}$ yang diperoleh pada penggunaan konsentrasi koloidal kitin $1 \%$ dan suhu $60^{\circ} \mathrm{C}$.
\end{abstract}

Kata kunci: Bora, sumber air panas, bakteri, termofilik, isolat B1211, kitinase. 


\section{LATAR BELAKANG}

Kitin merupakan biopolymer alam yang tersusun atas monomer $\beta-1,4 \mathrm{~N}$-asetil-Dglukosamin (Chen et al., 2010). Pada beberapa dekade terakhir, penelitian tentang kitin dan turunannya, seperti oligomer kitin, N-asetil-D-glukosamin, dan kitosan telah banyak dikembangkan. Hal tersebut tidak lepas dari manfaat dari produk-produk kitin yang banyak dimanfaatkan pada bidang kosmetik, biomedis, farmasi, dan pertanian (Purwani et al., 2002).

Pada produk hasil hidrolisis senyawa kitin banyak dimanfaatkan pada berbagai bidang, diantaranya bidang farmasi, pertanian dan industri makanan. Oligokitin dapat dimanfaatkan dalam membantu meningkatkan sistem kekebalan tubuh, memiliki sifat anti bakteri dan anti kapang, serta meningkatkan daya tahan pada tanaman. Semnetara untuk monomer $\mathrm{N}$ asetil-D-glukosamin sangat banyak dimanfaatkan sebagai obat untuk mengontrol kadar gula dalam darah, sebagai suplemen, dan anti inflamasi. Nasetil-D-glukosamin juga dapat digunakan di industri kosmetik dalam mengurangi hilangnya hiperpigmentasi (Herdyastuti et al., 2010).

Hidrolisis atau degradasi kitin dapat dilakukan secara kimiawi maupun enzimatik (Chen et al., 2010). Degradasi kitin secara enzimatis banyak dikembangkan karena merupakan memiliki yang sederhana, cepat, dan proses pemotongan ikatan glikosidik yang lebih spesifik untuk menghasilkan senyawa turunan kitin atau kitin oligosakarida dibandingkan hidrolisis kimiawi. Kitin oligosakarida dan N-asetil-D-glukosamin diperoleh dari proses degradasi secara enzimatik menggunakan enzim yang memiliki aktivitas kitinolitik, yaitu kitinase.

$$
\text { Kitinase (E.C. 3.2.1.14) dapat }
$$
dihasilkan dari beberapa jenis organisme, seperti serangga, crustacea, jamur, dan juga bakteri. Khusus untuk bakteri penghasil enzim kitinase, keberadaan enzim dapat dideteksi dan diisolasi melalui pembentukan zona bening pada medium selektif agar (Herdyastuti et al., 2010). Salah satu bakteri penghasil kitinase yang banyak mendapatkan perhatian adalah bakteri termofil, karena dapat menghasilkan enzim yang bersifat termostabil juga yang tahan pada suhu yang tinggi dan memiliki laju reaksi yang lebih cepat. Enzim termostabil dapat diperoleh dari bakteri yang hidup di daerah bersuhu tinggi seperti sumber air panas pada kawah gunung berapi, sumur hidrotermal, dan sebaginya. Bakteri termofil telah diisolasi dari sumur hidrotermal di Manado Sulawesi Utara dengan indeks kitinolitik 2,40 (Purwani et al., 2002). Selain indeks kitinolitik, aktivitas kitinase menjadi parameter penting lainnya dalam pemilihan isolat bakteri termofil terbaik. Pada penelitian sebelumnya Natsir et al., (2009) berhasil mengisolasi bakteri termofil (isolat ST-3) pada $\mathrm{pH} 7$ dan suhu $60^{\circ} \mathrm{C}$ dengan aktivitas kitinase $0,225 \mathrm{U} / \mathrm{mL}$. 
Indonesia yang banyak memiliki gunung berapi tentunya sejalan dengan melimpahnya sumber air panas, sehingga potensi ke arah isolasi bakteri termofil penghasil kitinase sangat besar. Salah satunya adalah sumber air panas Bora yang terletak di Kabupaten Sigi Provinsi Sulawesi Tengah. Sumber air panas Bora diasumsikan memiliki potensi besar sebagai tempat hidup dari bakteri-bakteri termofil sebagaimana sumber air panas Tompaso di Manado (Chasanah, 2004; Purwani et al., 2002). Belum adanya kajian yang menuju ke arah tersebut, sehingga perlu dilakukan isolasi bakteri termofilik asal air panas Bora untuk memproduksi enzim kitinase dengan aktivitas tinggi yang selanjutnya memiliki nilai ekonomi yang lebih tinggi.

\section{METODE PENELITIAN}

\section{Bahan dan Peralatan}

Bahan utama penelitian ini adalah sampel isolat bakteri B1211, media padat MSM dengan koloidal kitin (komposisi: $0,1 \% \quad \mathrm{KH}_{2} \mathrm{PO}_{4} ; \quad 0,7 \% \quad\left(\mathrm{NH}_{4}\right)_{2} \mathrm{SO}_{4} ; \quad 0.1 \%$ $\mathrm{NaCl} ; 0.05 \%$ ekstrak ragi, $1.5 \%$ agar, dan $2 \%$ koloidal kitin), kitin, MSM cair dengan kolidal kitin (komposisi: 0,1\% $\quad \mathrm{KH}_{2} \mathrm{PO}_{4}$; $0,7 \%\left(\mathrm{NH}_{4}\right)_{2} \mathrm{SO}_{4} ; 0.1 \% \mathrm{NaCl} ; 0,01 \% ; 0.05 \%$ ekstrak ragi, dan $0.5 \%$ koloidal kitin), bufer fosfat $\mathrm{pH} \mathrm{7,} \mathrm{NaCl}$ fisiologis, $\mathrm{HCl}$ pekat, $\mathrm{NaOH} 12 \mathrm{~N}$, glass wool, $\mathrm{NaCl}$, dan aquades. Bahan lainnya untuk analisis meliputi: pewarna Schales, dan N-asetil-Dglukosamin standar.
Alat yang digunakan meliputi spektrofotometer UV-Vis, inkubator, laminar air flow, sentrifugasi, penangas air , pipet mikro, vortex, botol sampel, dan alatalat gelas yang umum digunakan di laboratorium kimia.

\section{Prosedur Penelitian}

Produksi enzim kitinase (Modifikasi Metode Purwani dkk., 2002)

Kultur awal bakteri (starter) dibuat dengan menggunakan stok isolat bakteri termofilik B1211 hasil peremajaan disuspensikan pada $50 \mathrm{~mL}$ larutan fisiologis $0,9 \% \mathrm{NaCl}$. Produksi enzim kitinase diawali dengan sebanyak satu $\mathrm{mL}$ inokulum diambil dan dipindahkan pada media starter yaitu media MSM cair (tanpa koloidal kitin) dan diinkubasi pada suhu $37^{\circ} \mathrm{C}$ selama 24 jam. Langkah selanjutnya diambil sebanyak $1 \mathrm{~mL}$ isolat bakteri dan dipindahkan pada media produksi (MSM cair diperkaya koloidal kitin 0,$25 ; 0,5 ; 1$; $2 \%$, dan 4\%). Kemudian diinkubasi menggunakan termoshake pada kecepatan $60 \mathrm{rpm}$ selama tiga hari pada suhu $30(r t)$, 37,50 , dan $60^{\circ} \mathrm{C}$. Sentrifugasi pada 10.000 rpm selama 15 menit. Supernatan yang diperoleh adalah ekstak enzim kitinase kasar yang siap diujikan.

\section{Uji Aktivitas kitinase}

Pengujian aktivitas kitinase dilakukan dengan menggunakan metode Ueda dan Arai (1992) dengan beberapa modifikasi. Sebanyak $300 \mu \mathrm{l}$ koloidal kitin (1\%), $150 \mu \mathrm{l}$ buffer fosfat $\mathrm{pH} 7$ dan $150 \mu \mathrm{l}$ enzim kasar enzim dihomogenisasi dalam tabung reaksi 
dan diinkubasi pada suhu $55^{\circ} \mathrm{C}$ selama 30 menit. Pengujian dilakukan dengan ditambahkan reagen Schales. Hasil perlakuan diukur absorbansinya pada $\lambda=$ $420 \mathrm{~nm}$. Pengukuran konsentrasi N-asetilD-glukosamin hasil hidrolisis dihitung berdasarkan kurva standar $\mathrm{N}$-asetil-Dglukosamin. Satu unit aktivitas enzim kitinase didefinisikan sebagai sejumlah enzim yang menghasilkan satu $\mu$ mol $\mathrm{N}$ asetil-D-glukosamin per menit.

\section{HASIL DAN PEMBAHASAN}

\section{Aktivitas Enzim Kitinase}

Produksi enzim kitinase dari mikroorganisme lebih baik dibandingkan kitinase dari sumber yang lain karena kemudahannya berkembang biak dalam waktu yang relatif singkat. Produksi enzim kitinase dilakukan dengan menumbuhkan isolat bakteri pada media yang mengandung kitin sebagai substrat dan diinkubasi pada waktu, $\mathrm{pH}$, dan suhu tertentu. Isolat bakteri B1211 yang digunakan telah dilaporkan memiliki aktivitas kitinolitk dan dapat digunakan juga untuk produksi kitosanase (Khoridah, 2016). Faktor waktu, pH, dan suhu inkubasi perlu dikontrol untuk mendapatkan produksi enzim yang maksimal (Herdyastuti, 2009).

Deteksi kinerja enzim kitinase terlihat dari pengukuran aktivitas selama mendegradasi substrat. Substrat yang digunakan untuk mengukur aktivitas kitinase yaitu koloidal kitin. Aktivitas kitinase merupakan ukuran jumlah produk yang dihasilkan dari suatu pemecahan substrat kitin. Aktivitas kitinase ditentukan dengan menggunakan metode Schales, yaitu menggunakan reagen berwarna dan diukur menggunakan spektrofotometer UVVis pada panjang gelombang $420 \mathrm{~nm}$.

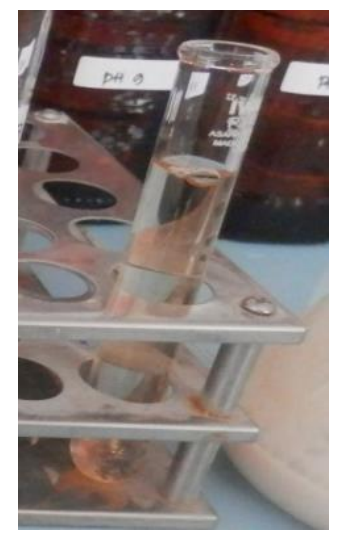

Gambar 1. Enzim kitinase kasar

Enzim kitinase diperoleh setelah masa inkubasi selama tiga hari dan sentrifugasi (Gambar 1). Berdasarkan Gambar 2 terlihat bahwa pada suhu ruang $\left( \pm 30^{\circ} \mathrm{C}\right)$ konsentrasi substrat stabil hingga $1 \%$ dan terjadi penurunan pada konsentrasi substrat $2 \%$, sedangkan pada suhu $37^{\circ} \mathrm{C}$, $50^{\circ} \mathrm{C}$, dan $60^{\circ} \mathrm{C}$ mengalami kenaikan sampai pada konsentrasi substrat $1 \%$ dan cenderung konstan pada konsentrasi substrat $2 \%$ dan 4\%. Michaelis-Menten menjelaskan tentang terjadinya kompleks enzim substrat karena adanya kontak antara bagian aktif enzim dan substrat. Sehingga pada konsentrasi enzim yang tetap, kecepatan reaksi akan meningkat seiring dengan penambahan substrat, karena semakin tinggi konsentrasi substrat maka semakin banyak yang bereaksi dengan sisi aktif enzim. Akan tetapi pada keadaan substrat berlebih, kerja enzim 
tidak sampai menurun tetapi konstan dimana enzim menjadi jenuh oleh substratnya, dan tidak dapat berfungsi lebih cepat. Kejenuhan terjadi karena seiring dengan meningkatnya konsentrasi substrat, semakin banyak enzim bebas yang diubah menjadi kompleks substratenzim ES (Lehninger, 1982).

Sementra pada penggunaan beragam suhu inkubasi menunjukkan bahwa kenaikan suhu produksi enzim kitinase mulai dari suhu ruang $\left( \pm 30^{\circ} \mathrm{C}\right)$ hingga suhu $60^{\circ} \mathrm{C}$ dengan aktivitas tertinggi sebesar $0,75 \mathrm{U} / \mathrm{mL}$ (Gambar 2). Kenaikan temperatur sampai pada batas nilai tertentu, dapat mempercepat proses reaksi kimia, tetapi kenaikan suhu yang terlalu tinggi atau setelah melebihi suhu optimumnya akan menyebabkan terjadinya denaturasi enzim. Hal ini menyebabkan terjadinya penurunan kecepatan reaksi yang dikatalis oleh enzim tersebut (Brock dan Brock dalam Dessy, 2008).

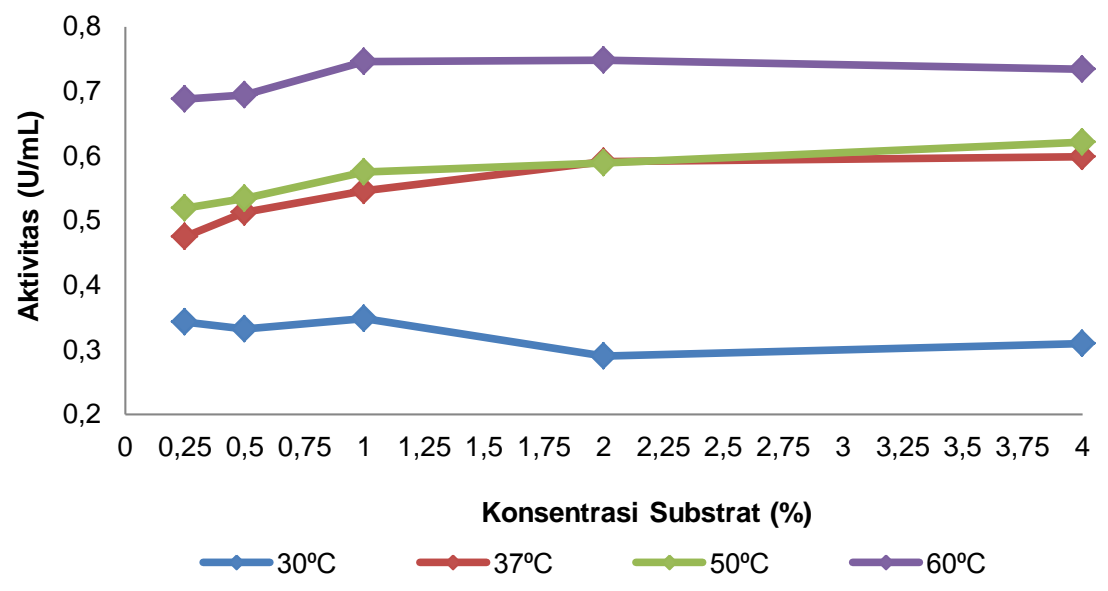

Gambar 2 Hubungan antara aktivitas enzim kitinase terhadap konsentrasi koloidal kitin dan suhu.

Natsir dkk., (2012) melaporkan bahwa enzim kitinase dari $B$. licheniformis HSA31a yang diproduksi pada suhu $50^{\circ} \mathrm{C}$ selama 72 jam inkubasi memiliki aktivitas 0,45 $\mathrm{U} / \mathrm{mL}$, sedangkan pembanding kitinase murni memiliki aktivitas 1,05 $\mathrm{U} / \mathrm{mL}$. Aktivitas enzim kitinase yang diperoleh pada penelitian ini lebih tinggi daripada enzim kitinase pada penelitian tersebut dan mendekati aktivitas kitinase murni, sehingga sangat potensial untuk selanjutnya dapat dimurnikan.

\section{KESIMPULAN}

Berdasarkan hasil penelitian yang telah dilakukan, dapat disimpulkan bahwa Enzim kitinase yang dihasilkan dari isolat bakteri termofil B1211 menghasilkan aktivitas tertinggi pada penggunaan konsentrasi substrat $1 \%$ dan suhu produksi $60^{\circ} \mathrm{C}$, yaitu $0,75 \mathrm{U} / \mathrm{mL}$.

Merujuk dari hasil penelitian yang diperoleh, dimana aktivitas enzim kitinase yang dihasilkan cukup tinggi, maka perlu dilakukan penelitian lanjutan berupa pemurnian kitinase dan juga pemanfaatan 
pada produksi oligomer kitinase maupun monomer $\mathrm{N}$-asetilglukosamin.

\section{UCAPAN TERIMAKASIH}

Ucapan terimakasih penulis haturkan kepada pihak DRPM Kemenristek Dikti yang telah memberikan hibah penelitian.

\section{DAFTAR PUSTAKA}

Chasanah E. 2004. Chitosanase of Bacillus luchenformis MB-2 Isolatd form Manado Hot Spring Water. Disertasi. Bogor: Program Pascasarjana. Institut Pertanian Bogor.

Chen JK, Shen CR, Liu CL. 2010. NAcetylglucosamine: Production and Applications (Review). Marine Drugs. 8: 2493-2516.

Dessy, C.S. 2008. Isolasi Bakteri dan Uji Aktivitas Amilase Termofil Kasar dari Sumber Air Panas Penen Sibirubiru Sumatera Utara. Tesis. Medan: Universitas Sumatera Utara.

Herdyastuti N, Raharjo TJ, Mudasir, Matsjeh S. 2009. Chitinase and Chitinolytic Microorganism: Isolation, Characterization and Potential. Indonesian Journal Chemistry. 9(1): 37-47.

Khoridah, E.N. 2015. Produksi Enzim Kitosanase dari Isolat Bakteri Termofil Sumber Air Panas Bora. Skripsi. Palu: Universitas Tadulako.

Lehninger AL. 1982. Dasar-Dasar Biokimia Jilid 1, (diterjemahkan oleh Meggy Thenawijaya). Jakarta: Erlangga.

Natsir H, Dali S, Astin, Trisanova. 2009. Isolasi dan Karakterisasi Enzim Kitinase dari Bakteri Termofil Isolat ST-3,2b. Jurnal IImiah Biologi Makassar. 4(1): 51-58.

Natsir H, Patong A.R, Suhartono M.T, dan Ahmad A. 2012. Produksi dan Aplikasi Kitinase dari $B$. licheniformis HSA3-1a dalam Menghidrolisis Kitin dari Limbah Udang dan Dinding Sel Jamur

Ganoderma http://repository.unhas.ac.id/handle/1 23456789/1643. Diakses pada tanggal 23 Agustus 2016).

Purwani EY.,Toharisman A, Chasanah E, Laksmi JF, Welan V, Suhartono, Purwadaria T, Hwang JK, Pyun YR. 2002. Studi Pendahuluan Enzim Kitinase Extraseluler yang Dihasilkan Oleh Isolat Bakteri Asal Manado. Jurnal Teknologi dan Industri Pangan. 8(2): 111-117.

Ueda M, Arai M. 1992. Purification and Some Properties of Chitinases from Aeromonas sp. No. 1OS-24. Biosci. Biotech and Biochem. 56(3): 460464. 